\title{
Biopsy of Salivary Gland
}

National Cancer Institute

\section{Source}

National Cancer Institute. Biopsy of Salivary Gland. NCI Thesaurus. Code C51488.

Removal of tissue from the salivary gland for microscopic examination. 